\title{
Rare earth $\beta$-diketonate and carboxylate metal complexes as precursors for MOCVD of oxide films
}

\author{
N.P. KUZMINA, L.I. MARTYNENKO, Z.A. TU, A.R. KAUL, G.V. GIRICHEV, N.I. GIRICHEVA, \\ A.N. RYKOV and Y.M. KORENEV
}

Department of Chemistry, Moscow State University, Moscow 119899, Russia

\begin{abstract}
Volatile and thermostable complexs of lanthanide acetylacetonates and pivalates were obtained and investigated by different methods. These compounds were used for lanthanide oxide containing film producing and for fabrication of silica optical fibers doped by lanthanide oxide. The properties of these and already known volatile precursors are compared.
\end{abstract}

It is well recognized that rare earth containing films have many applications in microelectronics. Metal Organic Chemical Vapour Deposition (MOCVD) has become one of the most effective methods for producing of thin films. This technique needs volatile and thermostable lanthanide compounds. There are two groups of volatile lanthanide compounds which can be sublimated at relatively low temperature $\left(120-400^{\circ} \mathrm{C}\right)$ - chelate complexes with organic ligands (with $\mathrm{M}-0$ or/and $\mathrm{M}-\mathrm{N}$ bonds) and organometallics (with $\mathrm{M}-\mathrm{C}$ bonds). The organolanthanides are air- and moisture-sensitive that is a specific property of $\mathrm{M}-\mathrm{C}$ bond. These sensitive compounds have been used only for doping semiconductors of rare earth by MOCVD[1].

The volatile lanthanide chelate complexes with organic ligands such as 1,3-diketonates have been successfully used to produce lanthanide containing oxide films, f.e. yttrium aluminium garnet and high temperature superconductors[2,3]. Lanthanide complexes with organic 0 -donor ligands are compounds with mainly ionic bonds and with high value of central rare earth ion coordination number. These properties are attributable to associated structure of lanthanide $\beta$-diketonates. Only bulky ligands are capable 
to inhibit association and promote volatility. Bulky 2,2,6,6,tetramethyl-3,5-heptanedione ligand (Hthd, also termed dipivaloylmethane) is the most useful for preparing volatile lanthanide $\beta$-diketonates. The main idea of our work is search for new volatile lanthanide compounds and the comparison of their behavior with that of known volatile compounds in CVD processes. It was found that such accessible and inexpensive lanthanide $\beta$-diketonates as acetylacetonates (acac, also termed penthane2,4-dionate) and pivalates (Piv, also termed trimethylacetates) can be sublimated and used for film producing.

\section{Volatile lanthanide acetylacetonates.}

It is known that lanthanide acetylacetonates $\operatorname{Ln}(\mathrm{acac})_{3}$ are of oligomeric structure and due to this are practically nonvolatile. Usually these compounds are synthesized as hydrates $\left.\operatorname{Ln}_{(\mathrm{acac}}\right)_{3}$ $3 \mathrm{H}_{2} \mathrm{O}$ :

$\mathrm{LnX}_{3}+3 \mathrm{HaCaC}+3 \mathrm{NH}_{3} \cdot \mathrm{aq} \longrightarrow \longrightarrow \operatorname{Ln}(\mathrm{acac})_{3} \cdot 3 \mathrm{H}_{2} \mathrm{O} \quad\left(\mathrm{H}_{2} \mathrm{O}, \mathrm{pH} 7\right)$ Hydrolysis and decomposition of these compounds occur when heated:

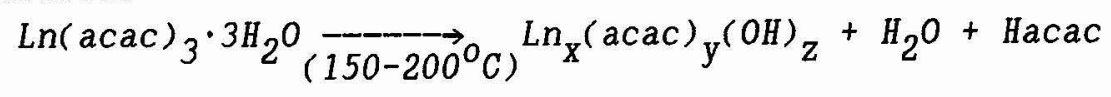

As an example, thermal decomposition of $\mathrm{Y}(\mathrm{acac})_{3} 3_{2} \mathrm{O}$ was shown to give $\mathrm{Y}_{4}(\mathrm{acac}){ }_{10}(\mathrm{OH})_{2}[4]$.

The mixed ligand complex formation have been used for modification acetylacetonate volatility. The volatile and thermostable forms of lanthanide acetylacetonates were prepared by reactions of nonvolatile acetylacetonate hydrates and 0 - or $\mathrm{N}$-donor neutral ligands (Q):

$$
\operatorname{Ln}(\mathrm{acac})_{3} \cdot 3 \mathrm{H}_{2} \mathrm{O}+\mathrm{nQ} \longrightarrow \longrightarrow \operatorname{Ln}(\mathrm{acaC})_{3} \cdot \mathrm{nQ}+3 \mathrm{H}_{2} \mathrm{O} \text {, }
$$

where $Q$ is o-phenantroline(Phen)[5], HMPA[6], acetylacetonimine (HAcim) [7], $\mathrm{n}=1,2$.

The adducts $\operatorname{Ln}(\mathrm{acac})_{3} \cdot \mathrm{nQ}$ were investigated in solid state and in gaseous phase by IR and thermal analysis, mass spectrometry, photoelectron spectroscopy. It was found that addition of the neutral donor ligands $Q$ was accompanied by formation of adducts which did not hydroluse when heated. Three different modes of adducts $\mathrm{MAA}_{3} \cdot \mathrm{nQ}$ sublimation were demonstrated:

(1) $M(a c a c)_{3} \cdot n Q_{(s)} \underset{100-150^{0}}{-} M(a c a c)_{3(s)}+n Q_{(g)}$

$$
\overrightarrow{150-200^{\circ}} M(\operatorname{acac})_{3(g)}
$$


(2) $M(a c a c)_{3} \cdot n Q_{(s)} \underset{150-200^{0}}{M(a c a c)_{3(g)}}+M(a c a c)_{3} \cdot n Q_{(g)}+n Q_{(g)}$

(3) $\left.M(a c a c)_{3} \cdot n Q_{(s)}-\underset{220-240^{\circ}}{M(a c a c}\right)_{3} \cdot n Q_{(g)}$

The volatility of $\mathrm{MAA}_{3} \cdot \mathrm{nQ}$ depends on nature of the lanthanide ion and the donor ligand and can be varied. Data of table 1 illustrate these dependencies for typical elements of cerium and yttrium groups of lanthanides.

Table 1.

Results of mixed ligand complexes $\mathrm{LnAA}_{3} \cdot \mathrm{nQ}$ sublimation ( 0.01torr, $220^{\circ} \mathrm{C}, 60 \mathrm{~min}, 0.2 \mathrm{~g}$ )

\begin{tabular}{|l|c|c|c|}
\hline \multicolumn{1}{|c|}{ Compound } & $\begin{array}{c}\text { Mass loss } \\
\text { (mol.\% of RE, } \pm 5 \%)\end{array}$ & $\begin{array}{c}\text { Mode } \\
\text { of sublimation }\end{array}$ & Ref. \\
\hline $\mathrm{NdAA}_{3} \cdot$ Phen & 100 & 3 & {$[5]$} \\
$\mathrm{GdAA}_{3} \cdot$ Phen & 100 & 3 & {$[5]$} \\
$\mathrm{ErAA}_{3} \cdot$ Phen & 100 & 3 & {$[5]$} \\
$\mathrm{YAA}_{3} \cdot$ Phen & 100 & 3 & {$[5]$} \\
$\mathrm{NdAA}_{3} \cdot \mathrm{HMPA}$ & 40 & 2 & {$[6]$} \\
$\mathrm{GdAA}_{3} \cdot \mathrm{HMPA}$ & 60 & 2 & {$[6]$} \\
$\mathrm{ErAA}_{3} \cdot \mathrm{HMPA}$ & 95 & 2 & {$[6]$} \\
$\mathrm{YAA}_{3} \cdot \mathrm{HMPA}$ & 90 & 2 & {$[6]$} \\
$\mathrm{NdAA}_{3} \cdot$ 2HAcim & nonvol. & 1 & {$[7]$} \\
$\mathrm{GdAA}_{3} \cdot 2 \mathrm{HAcim}$ & nonvol. & 1 & {$[7]$} \\
$\mathrm{ErAA}_{3} \cdot \mathrm{HAcim}$ & 80 & 1 & {$[7]$} \\
$\mathrm{YAA}_{3} \cdot \mathrm{HAcim}$ & 70 & 1 & {$[7]$} \\
\hline
\end{tabular}

The enthalpies of $\mathrm{NdAA}_{3}$, $\mathrm{HoAA}_{3}, \mathrm{ErAA}_{3}$ sublimation were calculated from mass spectrometric data (table 2) [8]. The values of $\Delta \mathrm{H}_{\text {sub }}$ for known lanthanide dipivaloylmethanates [9] are given in table 2 in order to compare with the ones for lanthanide acetylacetonates. The comparison shows that $\Delta \mathrm{H}_{\text {sub }}$ of monomeric lanthanide acetylacetonates are quite close to that of dipivaloylmethanates. However the mass spectrometric data demonstrate that 
Lnthd $_{3}$ decompose in gaseous phase at more high temperature than acetylacetonates. The thermal stability of $\mathrm{Ythd}_{3}$ have been investigated in vapour[10]. Its stability temperature range extends up to $500-550^{\circ} \mathrm{C}$. Lanthanide acetylacetonates decompose in vapour at $\sim 400^{\circ} \mathrm{C}$.

Table 2

The enthalpy of sublimation of lanthanide acetylacetonates[8] and dipivaloylmethanates [9].

\begin{tabular}{|l|c|c|}
\hline Compound & $\Delta \mathrm{H}_{\text {sub }}, \mathrm{kcal} / \mathrm{mol}$ & Temperature range, $\mathrm{K}$ \\
\hline $\mathrm{NdAA}_{3}$ & $34.6 \pm 1.6$ & $392-408$ \\
$\mathrm{HoAA}_{3}$ & $33.2 \pm 1.8$ & $385-417$ \\
$\mathrm{ErAA}_{3}$ & $31.0 \pm 1.8$ & $365-417$ \\
Ndthd $_{3}$ & $37.9 \pm 1.2$ & $430-491$ \\
Hothd $_{3}$ & $31.4 \pm 1.1$ & $420-458$ \\
Erthd $_{3}$ & $31.8 \pm 1.2$ & $410-454$ \\
\hline
\end{tabular}

\section{Volatile lanthanide pivalates.}

Lanthanide pivalates belong to the class of complexes with carboxylate organic ligands. It is thought to be unexpected result that lanthnide carboxylates are volatile. These lanthanide compounds are ionic and polymeric and as rule they are non volatile [11]. However pivalates contain bulky alkyl group - t-butyl which promotes decreasing of intermolecular forces and increasing of volatility. Besides that lanthanide pivalates were obtained in form of coordination saturated compounds - $\operatorname{LnPiv}_{3} \cdot \mathrm{HPiv}(\mathrm{n}=3$, $3.5)$ with coordination number equal 8 . The adducts $\operatorname{LnPiv}_{3} \cdot \mathrm{nHPiv}$ have been investigated by different methods: IR, TA, x-ray analysis, mass spectrometry and sublimation. A comparison of the IR spectra of $\mathrm{LnPiv}_{3} \cdot \mathrm{nHPiv}$ with those of HPiv indicates an coordination between the carboxylic $\mathrm{C}=0$ and metal ion: band characteristic of the $\mathrm{CO}_{2} \mathrm{H}$ gpoup of $\mathrm{Hpiv}\left(1710 \mathrm{~cm}^{-1}\right)$ shifts to lower frequence $\left(1700-1690 \mathrm{~cm}^{-1}\right.$ ) in the spectra of $\mathrm{LnPiv}_{3} \cdot$ nHPiv. By determining the crystal structure of $\mathrm{NdPiv}_{3} \cdot 3 \mathrm{HPiv}$ was showed that it was a dimer. It is shown that two processes take place when heating $\operatorname{LnPiv}_{3} \cdot \mathrm{nHPiv}$ at low pressure (40 torr, $\mathrm{N}_{2}$ ): formation of $\mathrm{MPiv}_{3}$ 
below $200^{\circ} \mathrm{C}$ and sublimation of $\mathrm{MPiv}_{3}$ in temperature range $330-$ $400^{\circ} \mathrm{C}$. The compounds $\mathrm{MPiv}_{3}$ decompose at $450-550^{\circ} \mathrm{C}$ with lanthanide oxide formation. Unlike MPiv ${ }_{3} \cdot n H P i v$ carboxylates $\mathrm{MPiv}_{3}$ are airand moisture-sensitive. Adducts $\mathrm{MPiv}_{3} \cdot \mathrm{nHPiv}$ have excellent storage characteristics and are used for sublimation study (tabl. 3 ).

Table 3.

The results of lanthanide pivalates sublimation ( 0.01 torr, $90 \mathrm{~min}, 0.2 \mathrm{~g}$ )

\begin{tabular}{|l|c|c|c|c|}
\hline Compound & $\mathrm{T},{ }^{\circ} \mathrm{C}$ & $\begin{array}{c}\text { Mass loss, } \\
\mathrm{mol} . \% \mathrm{RE} \\
\pm 2 \%\end{array}$ & $\mathrm{~T},{ }^{\circ} \mathrm{C}$ & $\begin{array}{c}\text { Mass loss, } \\
\mathrm{mol} \% \mathrm{RE} \\
\pm 2 \%\end{array}$ \\
\hline LaPiv $_{3} \cdot 3.5 \mathrm{HPiv}$ & 330 & 95 & 390 & 98 \\
PrPiv $_{3} \cdot 3 \mathrm{HPiv}$ & $"$ & 95 & $"$ & 98 \\
$\mathrm{NdPiv}_{3} \cdot 3 \mathrm{HPiv}$ & $"$ & 95 & $"$ & 95 \\
$\mathrm{GdPiv}_{3} \cdot 3 \mathrm{HPiv}$ & $"$ & 90 & $"$ & 95 \\
$\mathrm{HoPiv} \cdot 3 \mathrm{HPiv}$ & $"$ & 45 & $"$ & 95 \\
$\mathrm{ErPiv}_{3} \cdot 2.5 \mathrm{HPiv}$ & $"$ & 35 & $"$ & 98 \\
$\mathrm{YbPiv}_{3} \cdot 2.5 \mathrm{Piv}$ & $"$ & 30 & $"$ & 95 \\
$\mathrm{YPiv}_{3} \cdot 2.5 \mathrm{HPiv}$ & $"$ & 20 & $"$ & 95 \\
\hline
\end{tabular}

The sublimation experiments have shown that the difference in volatilities of $\mathrm{MPiv}_{3} \cdot \mathrm{nHPiv}$ formed by lanthanides of yttrium and cerium groups has been attributed to differences in sublimation kinetics. The kinetic factors strongly effectlanthanide pivalate sublimation because these compounds have oligomeric structures. Mass spectroscopy data demonstrate their trimeric or dimeric structures in vapour: $\operatorname{Ln}_{3} \mathrm{Piv}_{5}{ }^{+}, \mathrm{Ln}_{2} \mathrm{Piv}_{4}{ }^{+}, \mathrm{LnPiv}_{2}{ }^{+}$at $654 \mathrm{~K}$. Partial thermal decomposition (3-5\%) of $\mathrm{LnPiv}_{3}$ was found under the conditions of mass spectrometric experiment. For usual sublimation experiments (40 torr, $\mathrm{N}_{2}$ ) partial thermal decomposition of LnPiv $_{3}$ appears only in presence of moisture traces in carrier gas. The vapor densities of $\mathrm{NdPiv}_{3}$ and $\mathrm{ErPiv}_{3}$ were determined by flow methods in the temperature range of $330-370^{\circ} \mathrm{C}$. The obtained values of density are about $3 \cdot 10^{-4} \mathrm{~mol} / \mathrm{ml}$ what is close to ones for lanthanide dipivaloylmethanates but the latters sublimate at 
lower temperature $\left(150-200^{\circ} \mathrm{C}\right)$. Another advantageof lanthanide pivalates is their accessibility and low price when compared with dipivaloylmethanates.

\section{The use of volatile lanthanide acetylacetonates and pivalates for MOCVD}

Complexes $\operatorname{Ln}(\text { acac })_{3}$. Phen and Lnthd $_{3}$ are used as dopants in the MOCVD method for fabrication of single-mode and multi-mode silica optical fibers where the core is doped by RE in the level of 0.1$3000 \mathrm{ppm}$. The fiber preforms are fabricated by MOCVD process with deposition of the glass core as a porous layer. It was demonstrated that the type of $R E$ complex did not change the amount of OHgroups in the glass core. The content of $\mathrm{OH}$ groups is not higher than $1 \mathrm{ppm}$ without any additional drying [12].

\section{References}

[1] DEACON G.B., MACKINON P., DICKSON K.S. et al., Appl. Organomet. Chem. 4 (1990) 439

[2] DHANAVATRI C., KARECA R.N, RAO V.J., Thin solid film 127 (1985) 85

[3] GORBENKO 0.Yu., KAUL A.R., GRABOY I.E. et al., Physica C 190 (1991) 180

[4] BARASH E.U., COAN P.S., LOBKOVSKY E.B. et al., Inorg. Chem. 32 (1993) 497

[5] DZYUBENKO N.G., MARTYNENKO L.I., Zhurnal Neorganitseskoi Chimi i 29 (1984) 691

[6] KUZMINA N.P., CHECHERNIKOVA M.V., MARTYNENKO L.I. et al., Zhurnal Neorganitseskoi Chimi 31 (1986) 3016

[7] TREMBOVETSKIYI G.V. BERDONOSOV S.S., MARTYNENKO L.I. et al., Zhurnal Neorganitseskoi Chimii 30 (1985) 1163

[8] KUZMINA N.P., SEMJANNIKOV P.P., CHEU THI NGUET et al,, Zhurnal Neorganitseskoi Chimii 35 (1991) 487

[9] SICRE J.E., DUBOIS J.T., EISENTRAUT K.J. et al., J. Amer. Chem. Soc. 91 (1969) 3476

[10] Girichev G.V., GIRICHEVA N.I., KAUL A.R. et al., Zhurnal Neorganitseskoi Chimii 37 (1993) 789

[11] GMELIN Handbook of inorganic chemistry D5 (1984)

[12] LORJAN R.,ZAYTZ A.I., KUZMINA N.P. et al., Avt. svid.SSSR, N1776646 (24.05.1990) 